3-31-2019

\title{
Constitutionality of Non-Contentious Cases in Japan
}

Thomas Makoto Naruse

Faculty of Law, Kokushikan University

Follow this and additional works at: https://gensoken.toyo.ac.jp/japanese-society-and-culture

Part of the Constitutional Law Commons, and the Japanese Studies Commons

\section{Recommended Citation}

Naruse, Thomas Makoto (2019) "Constitutionality of Non-Contentious Cases in Japan," Japanese Society and Culture: Vol. 1 , Article 3.

DOI: $10.52882 / 2434-1738-2$

Available at: https://gensoken.toyo.ac.jp/japanese-society-and-culture/vol1/iss 1/3

This Article is brought to you for free and open access by Institute of Social Sciences. It has been accepted for inclusion in Japanese Society and Culture by an authorized editor of Institute of Social Sciences. 


\title{
Constitutionality of Non-Contentious Cases in Japan
}

\section{Thomas Makoto Naruse*}

\begin{abstract}
In the United States, there was a debate on vesting Article 3 Court extrajudicial authorities, and United States Supreme Court have often denied vesting such authority. In contrast, in Japan, extrajudicial authorities (including those without element of dispute) are vested in courts since the age of Meiji Constitution, and only recently, questions are posed. Today, many scholars are struggling with this issue, and some approaches are shown: one is to conceive the limit of authority which courts can handle according to the distance from properly judicial power, which has dispute as the core element, and the other is to change the definition of the judicial power, and conceive that dispute is not an requisite element of judicial power. However, there arise doubts on both of the approaches. This article introduces the debate concerning the limit of judicial power and noncontentious cases with references to the history, and then present a direction toward a new approach. Instead of discussing the topic in specific details, this articles introduces a brief overview of the topic.
\end{abstract}

Key Words: Judicial Power, Extrajuducial Authorities, Dispute, Separation of Powers, Constitution of Japan

\section{Forward}

Recently, there have been discussions about non-contentious cases in the United States; for example, the debate between Professor Pfander and Professor Woolhandler ${ }^{1}$. In the debate, it have been discussed that how to place non-contentious cases -an extrajudicial, non-adverse proceedingsunder Constitution ${ }^{2}$. On the other hand, in Japan, however non-contentious cases are conceived as extrajudicial authority, it is widely accepted and actively used. Non-contentious cases are divided into two categories, one where there has been a certain amount of adversity, and one lacking adversity. Unlike the Constitution of the United States, the Constitution of Japan does not stipulate the subject of jurisdiction in the express statement ${ }^{3}$. However, it has been conceptualized in a way that is somewhat similar to that of the United States. Moreover, unlike in the United

\footnotetext{
* Lecturer, Kokushikan University, Department of Law

1 James E. Pfander \& Daniel D. Birk, Article III Judicial Power, the Adverse-Party Requirement, and NonContentious Jurisdiction, 124 Yale L. J. (2015)., James E. Pfander \& Emily K. Damrau, A Non-Contentious Account of Article III'd Domestic Relations Exception, 92 Notre Dame L. Rev. 117(2016)., James E. Pfander \& Daniel Birk, Adverse Interests and Article III: A Reply, 111 Nw. U. L. Rev. 1067 (2017), Ann Woolhandler, Adverse Interests and Article III, 111 Nw. U. L. Rev. 1025 (2017),

2 See generally, articles listed in footnote 1.

3 Nihonkoku Kenpo[Constitution][Kenpo] art. 76, section 1 (Japan).
} 
States, it has not been questioned for many years about the constitutionality of vesting the courts authorities which are not within the judicial power by the legislature.

In recent years, doubts about giving the courts extrajudicial authority have been presented, and alternative theories have been discussed. As a fundamental stance of the doctrine, scholars try to justify the extrajudicial authorities of the courts. There, they try to justify authorization "from a distance" by the proper judicial power, in accordance with how close it is to the proper judicial power. However, as pointed out in my previous works, it is difficult to grasp non-contentious cases from such a viewpoint.

The purpose of this article is to introduce theories of non-contentious cases in Japan, by introducing a brief overview of the topic. Firstly, the article describes how judicial power was conceived in Japan. Then, describes the characteristics of non-contentious cases involving procedures introduced under the Meiji Constitution. Based on that, the article will draw out how non-contentious cases were defined under the Meiji Constitution, and how this was considered during the process of drafting the current Constitution. Finally, the article will present some doubts after touching upon the two views presented in recent articles on non-contentious cases.

The aim of this article was to introduce Japanese scholarly works in English There, please note that there are some overlapping in the contents with my previous works ${ }^{4}$.

\section{Conventional Views of Judicial Power, and Criticisms Made Against Them}

(1) Conventional Views of Judicial Power

Judicial power is articulated in Article 76, section 1 of the Constitution of Japan as "The whole judicial power is vested in a Supreme Court and in such inferior courts as are established by law. ${ }^{\text {" }}$ No provision provides definition of judicial power in the Constitution. However, Professor Kiyomiya defined it as "the functions of the state that apply and declare the law to concrete dispute, and decide that ${ }^{6}$." Although there are expressional differences, this definition is widely shared between academics and in practice.

What is noteworthy here is that despite the absence of provisions limiting the subject of jurisdiction seen in Article 3, Section 2, of the United States Constitution, the subject of judicial power is conceived to be limited to "concrete disputes." Here, the meaning of "concrete disputes" becomes a problem. Regarding this point, a reference is made to Article 3, section 1 of the Court Act, which is the law that embodies Article 76 of the Constitution. The same article defines the authority of the courts, as "Courts shall, except as specifically provided for in the Constitution of Japan, decide all legal disputes, and have such other powers as are specifically provided for by

\footnotetext{
${ }^{4}$ See generally, Naruse Thomas Makoto, Hishojiken to Shihoken [Non-Contencious Cases and Judicial Power], Vol.61 No.3 Toyo Hogaku 199-216 (2018) [hereinafter Non-Contencious Cases], Naruse Thomas Makoto, The Concept of "Injury" During the Formation of the Japanese Constitution and the Court Act, in Universality and Peculiarity of the Constitutions in the World 329 (Seibundo 2010) [hereinafter Injury].

${ }^{5}$ Kenpo art. 76.

${ }^{6}$ Kiyomiya Shiro, Horitsugaku Zenshu3 Kenpo I Shinban [Constitutional Law Vol.1 $2^{\text {nd }}$ ed.] 330 (Yuhikaku 1971).
} 
law ${ }^{7}$." Here, "legal dispute" is conceived to be synonymous with "concrete dispute." However, its content is not detailed in the text. In this regard, the precedents of the Supreme Court indicate views. A legal dispute is "a controversy concerning concrete rights or duties, or the existence of legal relations, between parties 8 " and "to be resolved with finality by the application of the law9." These requirements are also widely accepted in both academia and practice.

As mentioned above, a discussion of the range of judicial power in Japan has a complex appearance. When organized, the figure "judicial power in Article 76 of the Constitution = concrete dispute $=$ Legal dispute under Article 3 of the Court Act $=$ requirement presented by the supreme court 10 " is drawn. In such a discussion, it can be noted that the "self-understanding" of judicial power is purported to pursue a "private right model"11. Professor Shishido's analysis suggests that the court has fallen into excessive self-restraint, according to the view that the court finds its mission or essence in a non - authoritative civil suit ${ }^{12}$.

However, the authority of the court is not limited to the exercise of judicial power as above. Article 3, paragraph 1 of the above-mentioned Court Act defines that courts "have such other powers as are specifically provided for by law, ${ }^{13}$ " and the purpose of the article is to allow the exercise of powers other than "legal disputes," that is the exercise of judicial power. In other words, the Court Act enables the vesting of extrajudicial authorities in the courts. The first thing to mention about this point is the administration of judicial affairs, and the rulemaking power of the Supreme Court, stipulated by Article 77 of the Constitution. Since those powers are granted by the Constitution, those powers should not become a problem. The problem is the authority of a judicial decision that are considered as extrajudicial power, such as, "objective litigation (Kyakkan Sosho)" and the "non-contentious case." First of all, objective litigation is litigation that aims to guarantee objective legal appropriateness of laws or protect the interests of the general public ${ }^{14}$. It is distinct from "subjective litigation (Shukan Sosho), " authorities which are within judicial power, and the aim is to protect individual legal rights ${ }^{15}$. The difference is that proving the infringement of rights is not required in a subjective litigation, because the purpose is to ensure the legality of government actions, not the protection of personal rights. In addition, subjective litigation is the exercise of authority vested in the courts as an extrajudicial authority. Japan's dominant view defines administrative power as the power of the state excluding both legislative and judicial power ${ }^{16}$. Objective litigation and non-contentious cases do not fall within

\footnotetext{
7 Saibanshoho[Courts Act][Saibanshoho]art.3, section 1 (Japan) .

8 Vol.4 No.11, Saiko Saibansho Gyosei Jiken Saiban Reishu, 2761(Sup. Ct., Nov. 17, 1953).

9 Id.

10 Minamino Shigeru, Shihoken no Gainen [ The Concept of Judicial Power], in Yasunishi Fumio et al. Kenpogaku no Gendaiteki Ronten $2^{\text {nd }}$ ed. 178 (Yuhikaku 2009).

11 Shishido Joji, Shiho no Pragmatic [Pragmatic of Judiciary], 322 Hogaku Kyoshitsu 26 (2007).

12 Id.

13 Saibanshoho art.3, section 1.

14 Shiono Hiroshi, Gyoseiho II Gyosei Kyusaiho Daigohan [Administrative Law II Administrative Remedy Law $5^{\text {th }}$ ed.] 81 (Yuhikaku 2011).

15 Id.

16 Ashibe Nobuyoshi, Kenpo Dairoppan [Constitution $6^{\text {th }}$ ed.] 322-23 (Iwanami Shoten 2015).
} 
the remit of judicial power nor legislative power. Therefore, the logical conclusion is that such cases fall with the remit of administrative power.

In the United States, there was a debate on vesting Article 3 Courts with extrajudicial authority, and the United States Supreme Court has often denied vesting such authority. However, such a discussion has not been had for a long time in Japan. Like in the United States, in Japan, the separation of powers is interpreted as a constitutional principle. It has been pointed out that the conventional majority view is that the separation of powers should be applied strictly ${ }^{17}$. On the other hand, however, extrajudicial authority has been vested in courts, which involves the exercise of administrative power, and such a "contradiction" has been overlooked.

\section{(2) Criticisms Against the Majority Theory}

Criticisms have arisen in response to the majority view mentioned above. Professor Nosaka has pointed out that the majority view does not demonstrate the grounds for vesting extrajudicial authority in the court, and hardly seems to be aware of the problem ${ }^{18}$. Professor Minamino and Professor Takahashi also identified this problem ${ }^{19}$. In other words, in the conventional majority view, change in the distribution of authority are done by statute, despite the authorities are distributed by Constitution, and it is questionable whether such action is unconstitutional ${ }^{20}$. This criticism is based on a strict view of the separation of powers. In other words, under the Constitution, the principle of the separation of powers is defined, whereby power is divided and granted to different divisions. This distribution is a constitutional principle. Moreover, so-called objective litigation and non-contentious cases are considered to involve the exercise of authority outside of judicial power, which is not included in legislative power, so according to the majority view, it must fall within the remit of administrative power. However, the Constitution vests administrative power in the Cabinet. Thus, explanation and justification is needed for such changes by statute, and also, a line needs to be drawn to indicate to what extent it is possible. Claiming that objective litigation is unconstitutional is "too reckless ${ }^{21}$." Professor Shishido summarized the views of three representative constitutional law scholars, and all three of them argued the objective litigation (citizen's actions, interagency actions, and election suits) - which are an important means of legal control- constitutional, while drawing lines that make abstract judicial review unconstitutional22. Moreover, most other scholars of constitutional law have shared this stance. They took the approach that a limit must be drawn that defines when one can imitate a dispute ${ }^{23}$,

\footnotetext{
17 Muranishi Ryota, Kenryoku Bunritsuron no Gendaiteki Tenkai -Kinouteki Kenryoku Bunritsuron no Kanousei-[Modern Deployment of Separation of Powers-The Possibility of Functional Approach to Separation of Powers-], 90 Kyudai Hogaku 214, 231 (2015).

18 Nosaka Yasuji, Kenpo to Shihoken -Kenpojo no Shihoken no Toraekata wo Megutte [Constitution and Judicial Power], 246 Hogaku Kyoshitu 43 (2001).

19 Takahashi Kazuyuki, Taikei Kenpo Sosho [Theory of Constitutional Litigation] 33-34 ( Iwanami Shoten 2017) [hereinafter Litigation]. Minamino, supra note 10, at 177.

$20 \mathrm{Id}$.

21 Id.

22 Shishido, supra note 11 , at 26.

${ }^{23}$ See generally, Sato Koji, Nihonkoku Kenporon [Theory of Japanese Constitution] (Seibundo 2011).
} 
or enlarge the requirement of a "case." ${ }^{24}$ Still, both of those approaches share the construction of drawing a line with reference to the distance from the "proper judicial power", which is the "judicial power" defined in the Constitution. In other words, the concept of judicial power, and more specifically the concept of "dispute," has been the merkmal.

Non-contentious cases are the authorities very "far" from the "proper judicial power" defined in the Constitution. Non-contentious cases also existed under the Meiji Constitution and had been handed down under the current Constitution. In the following section, the article will see how noncontentious cases were conceived under the Meiji Constitution and during the process of drafting the current Constitution and the Court Act, to show how judicial power has been conceived and how the provision of extrajudicial authority has been justified.

\section{Non-Contentious Cases, and Their Historical Background}

\section{(1) Overview}

Non-contentious cases are defined as judicial proceedings that involve the processing of civil cases that are not litigation proceedings ${ }^{25}$. There are various kinds of non-contentious cases, and their degree of dispute varies. Among them, this article deals with non-disputational authorities. As a specific example, there is a procedure for changing one's name. To change one's name for legitimate reasons, permission from the family court is required. The petitioner is the person who wishes to change their name, who submits the petition and attached documents (usually "certificate of family register" and evidence proving the reason for the change). After being granted the permission of the court, the person then registers the change at a municipal office.

What is noteworthy here is that there are no parties to counter the proceedings; therefore, a "dispute" is not involved. The court examines the submitted documents or interviews and judges whether there are legitimate reasons for the change of name. It is very different both procedurally and practically from litigation process. Here, it should be noted that (1) non-disputional noncontentious case does not involve conflict resolution, and (2) the court plays a guardianship or supervisory function and carries out an administrative function in terms of its substantive meaning 26 .

This involves a wholly different type of process from the exercise of judicial power defined as "the functions of the state that apply and declare the law to concrete disputes, and decide that ${ }^{27}$." In the first place, a "dispute" does not exist, and there are no adverse parties. Therefore, the question arises about how such authority is positioned. History reveals that the concept of the non-contentious case was adopted under the Meiji Constitution, and continued during the process of drafting the present Constitution and the Court Act, up to the present day. By tracing its history below, this article shows (1) how the non-contentious case has been characterized historically, (2) how such extrajudicial

\footnotetext{
24 Nosaka, supra note 18. Nakagawa Takehisa, Gyoseijiken Sosho no Kaisei- Sono Zentei to naru Kouhouteki Eii- [Amendment of Administlative Case Litigation Act] 63 Koho Kenkyu 127 (2001).

25 Ito Susumu\& Mitsui Tetsuo eds., Chukai Hisho Jiken Tetsudukiho [Commentary Non-Contentious Case Procedures Act] 3 (Seirin Shoten 1986).

26 Shibutani Hideki, Sosho to Hisho [Litigation and Non-contentious Cases], 5 Rikkyo Homu Kenkyujo 5 (2012).

27 Kiyomiya, supra note 6 , at 330 .
} 
authority was conceived when it was incorporated into the present constitutional system, and (3) how a conflict with the separation of powers has been understood. There, this article look at the origins of non-contentious cases in the process of drafting the Constitution of Japan and the Court Act, after outlining how they were conceived under the Meiji Constitution.

(2) Position of Non-Contentious Cases Theoretically Under the Meiji Constitution

Although the history of non-contentious cases dates back to ancient times ${ }^{28}$, the former NonContentious Case Procedures Act (Hishojiken Sosho Hou) was enacted in Japan following the promulgation of the former Civil Code (Minpo) and the former Commercial Code (Shoho) in $1888^{29}$. Below I would like to outline the status of non-contentious cases by reviewing their conception under the Meiji Constitution.

Professor Uesugi defines judicial power as the authority that adjudicates the litigation of civil and criminal cases; and the non-contentious case does not involve litigation ${ }^{30}$. Then he argues that Article 57 of the Meiji Constitution prohibits judicial power from being assigned to other divisions, yet it is not a constitutional violation to refer a non-contentious case to the court ${ }^{31}$.

Professor Shimizu pointed out that as the Constitution vests judicial power in the courts; therefore, it is a constitutional violation to have any part of the jurisdiction of the civil and criminal litigation procedure decided by administrative divisions ${ }^{32}$. In this way, it is impossible to reduce the range of judicial power by statute, but it does not prevent vesting the courts with "special authority," that is not properly "judiciary." 33 As examples, non-contentious cases such as registration affairs, and election lawsuits are listed, and this view is similar to those that vest courts with authority in non-contentious cases and "objective litigation" by statute seen today ${ }^{34}$. In addition, it will be noticed here that any "special authority" refers to extrajudicial authority.

Professor Minobe defines judicial power both in a broad sense and in a narrow sense. When comparing it with legislative and administrative power, judicial power in a broad sense is regarded as all government functions in civil and criminal matters under the law ${ }^{35}$. On the other hand, judicial power in the narrow sense applies to civil and criminal litigation ${ }^{36}$. Here, "civil function." refers to the function of the state in private law relations in order to preserve private law orders ${ }^{37}$. The objective is to make laws between individuals and to protect and maintain existing laws

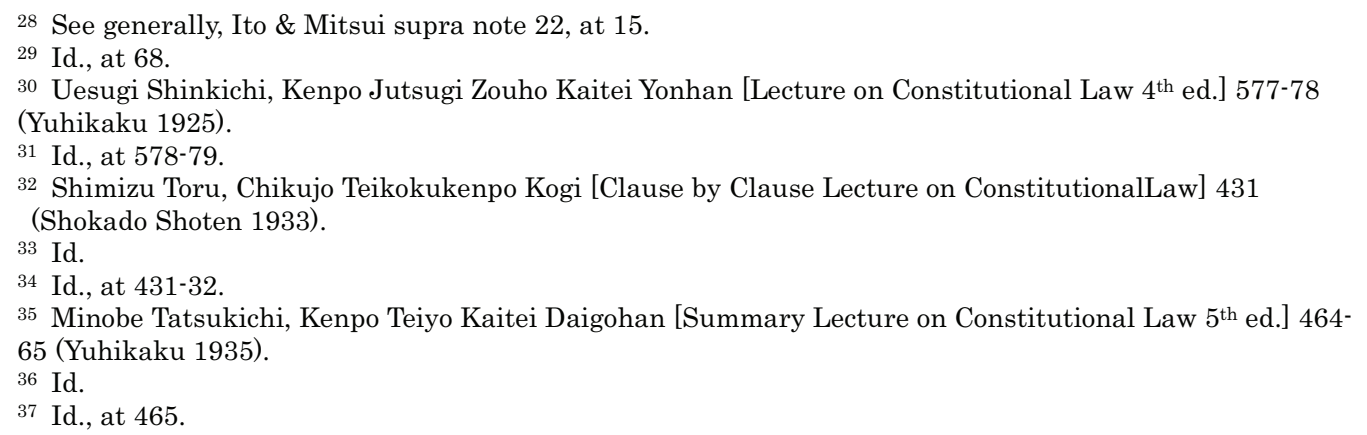


between individuals ${ }^{38}$. Here, it is noteworthy that law refers to "means" in other divisions, whereas the protection and maintenance of the law is the main "objective" of the courts ${ }^{39}$.

From a practical point of view, such civil functions can be divided into a "creative function" and "protective function." 40 The former involves the maintenance of civil legal order; and the state is involved in the formation of private law relations, such as bankruptcy declarations and disappearance declarations ${ }^{41}$. The latter function ensures the effectiveness of existing legislation, with confirmation, negotiation, and compulsory enforcement listed as the most important ${ }^{42}$.

From a practical point of view, the civil function is classified as described above, but from the procedural standpoint, it can be divided into civil lawsuits and non-contentious cases ${ }^{43}$. In contrast to civil lawsuits that involve civil functions through litigation processes conducted by proceedings, non-contentious cases do not have a civil function involving litigation processes; rather, the state function involves private legal relations under laws and regulations, not procedures of "dispute" 44 . In addition, the litigation process here refers to procedures involving adverse parties who are arguing about legal relations, while the state hears the arguments of both sides to make a judgment as a third party ${ }^{45}$.

Professor Minobe's viewpoint divides judicial power into a broad sense and a narrow sense, and in the broad sense, judicial power is conceived of very widely. However, in line with the interests of this article, "dispute" concerns the exercise of judicial power in a narrow sense, and non-contentious cases are not included. Professor Minobe's opinion conceives of judicial power broadly at first sight, which is consistent with other views, in that it separates non-contentious cases and litigation processes according to "dispute."

As mentioned above, under the Meiji Constitution, non-contentious case were regarded as beyond the remit of "litigation" or judicial power. It was understood that non-contentious cases are administrative functions that was vested in the court. Then, how did such an understanding was changed during the process of drafting the current Constitution? To answer this question, I shall turn to the process of drafting current Constitution and the Court Act.

(3) The Nature of the Non-Contentious Case in the Process of Drafting the Constitution of Japan and the Court Act 46

During the process of drafting the Constitution of Japan, the main issue concerning the clauses on judicial power was the transition of the jurisdiction of administrative case litigation to the judicial court, but the incidental reference was made to the range of judicial power ${ }^{47}$. In response

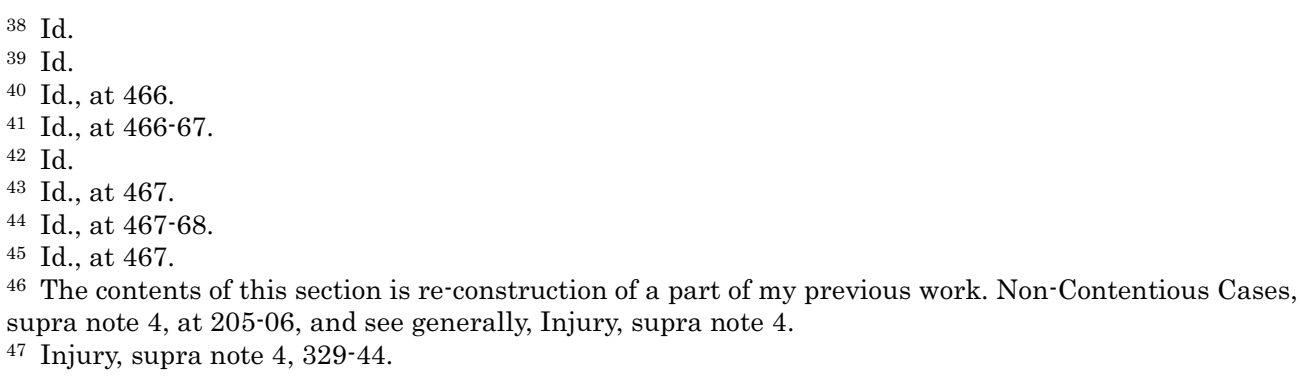


to a question, for example, in the deliberations of the Privy Council, Professor Minobe, who was also a member of the council, asked whether judicial power had the same meaning as jurisdiction, and minister Matsumoto responded that litigation involving the rights and obligations of citizens are within the remit of judicial power ${ }^{48}$. In the anticipated questions and answers prepared by the government prior to deliberation at the 90th Imperial Diet, a question about why we do not have an Austrian-style Constitutional Court was answered. Under the separation of powers, it is a natural thing to refuse to apply unconstitutional laws, according to "the nature of the judicial duties which adopts laws to pass judgment to the actual controversy concerning legal relations" 49 . Here, actual "dispute" is connected to the "nature" of judicial power ${ }^{50}$. In addition, during the committee of the House of Peers, one of the members insisted on the possibility of an abstract judicial review, but Minister Kanamori said that the court deals with the litigation of concrete cases only, therefore the Constitution requires concrete judicial review ${ }^{51}$. Although it was mentioned indirectly in this way, it was stated that judicial power is invoked when a "case" occurs, and deals with matters concerning the rights and duties of individuals. This view is similar to today's view ${ }^{52}$. It should also be pointed out that the concept of litigation was centered on the resolution of a "dispute" from here.

The major difference between the former and current Constitution involves the transition of authorities responsible for administrative cases, the creation of judicial review system, and review by the people ${ }^{53}$. However, judicial power is still invoked in cases concerning the rights and duties of individuals, in continuity with the former Constitution ${ }^{54}$. It is notable that, in 1949, the Constitution did not define the scope and meaning of judicial power clearly, and it seems to follow the concept as understood under the era of the Meiji Constitution ${ }^{55}$. Such continuity is also apparent in the continuity of the Court Act and the Court Constitution Act (Saibansho Kousei Hou) - a statute under the Meiji Constitution ${ }^{56}$.

The process of drafting the Constitution of Japan continued to define judicial power as a private right model, which involves a dispute resolution process and presupposes the existence of a case concerning legal rights and duties of individuals. Regarding non-contentious cases, the Minister of Justice Kimura said that it would be possible to vest the courts with the authority to process the

48 Irie Toshiro, Kenpo Seiritsu no Keii to Kenpojo no Shomondai Irie Toshiro Ronbunshu [Drafting Process of Japanese Constitution and Issues on Constitution] 331 (Yuhikaku 1976).

49 Sato Tatsuo, Nihonkou Kenpo Seiritsushi dai 3 kan [3 History of drafting process of Japanese Constitution] 479 (Sato Isao ed., Yuhikaku 1994).

$50 \mathrm{Id}$.

51 Stenographic Record of Special Committee on Amendment of Imperial Constitution, House of Peers, $90^{\text {th }}$ Imperial Diet, No.20, at 19-20.

52 See generally, Injury, supra note 4.

53 Shimizu Shin, Chikujo Nihonkoku Kenpo Shingiroku dai 3 kan [3 Clause by Clause Record of Deliberations on Japanese Constitution in Imperial Diet] 447-48 (Yuhikaku 1962).

54 Injury, supra note 4, 338-40.

55 Suzuki Takeo et al. eds., Chukai Nihonkoku Kenpo Chukan [2 Commentary on Japanese Constitution] 307 (Yuhikaku 1949). Id., at 301-02. It is also noteworthy that definition of judicial power appeared in professor Kiyomiya's work under Meiji constitution has similarities between his definition widely shared today. Kiyomiya Shiro, Kokkasayo no Riron [Theory of State Function] 23 (Yuhikaku 1968).

56 Naito Yorihiro, Shusengo no Shihoseido Kaikaku no Keika dai2 Bunsatsu [2 The Process of Reformation of Judicial System after World War II] 406 (Shiho Kenshujo 1959). 
family register, registration, mediation, and so on ${ }^{57}$. He said that the details were under consideration ${ }^{58}$, and the Court Act took on that "detail."

In the Court Act enactment process, the same view presented during the drafting the Constitution was discussed ${ }^{59}$. The second draft suggests that non-contentious cases are not within the remit of judicial power, and that the existence of "dispute" is referred to as merkmal60. Meanwhile, the third drafting explained that the meaning of "dispute" involves the assertion of the right to oppose an adverse party, and seek confirmation of their existence or non-existence ${ }^{61}$. From here too, the resolution of a "dispute" is the key activity of judicial power.

However, later there was a discussion in the Privy Council ${ }^{62}$. That is, at that point, the bill defined the court's authority extend to "legal disputes," however, if the court could handle authority such as a non-contentious case, it was claimed that vesting such extrajudicial authority should be defined in an article ${ }^{63}$. Initially, the government admitted that non-contentious cases were not "disputes"64, and the government insisted that it presupposed from the beginning the vesting of extrajudicial authority by statute, just like the system under the Meiji Constitution ${ }^{65}$. However, after being criticized, the government changed this attitude and included an explicit provision that enabled the vesting of extrajudicial authority in the courts by statute, which became the composition of the text as it is now.

\section{(4) Summary}

As we have seen above, in theory, non-contentious cases were also regarded as within the remit of extrajudicial authority under the Meiji Constitution. Some viewed such an authority as possessing an administrative function. During the drafting of the current Constitution and Court Act, "dispute" became a key concept defining the remit of judicial power. Non-contentious cases fell within the remit of a separate authority from litigation and judicial power.

However, as is clear from the discussion of the Court Act drafting process, the grounds for providing the court with extrajudicial power were not discussed. The government saw it as obvious. The objections were also only asking for clarification of the statute; however, no questions arose about the constitutionality of vesting such authority in the courts, despite the principle of separation of powers.

The issue concerning the separation of powers as seen in recent years has not been recognized. Non-contentious cases have rested in courts under the premise of a moderate view of separation of powers, and as Professor Nosaka pointed out, even during the process of drafting the Court Act,

\footnotetext{
57 Shimizu, supra note 53 , at 485 .

58 Id.

59 The contents below are based on my previous work. Non-Contentious Cases, supra note 4, at 204-06.

60 Naito, supra note 56, at 390.

61 Id., at 406.

62 The contents below are based on my previous work. Non-Contencious Cases, supra note 3, at 205-06.

63 Naito, supra note 56, 702-08.

${ }^{64}$ It should be noted that the view was shown that sees the concept of dispute with more flexibility and saw possibility to enlarge. Injury, supra note 4 , at 336 .

65 Naito, supra note56, at 705.
} 
the problems surrounding the constitutionality of granting such authority were not acknowledged consciously ${ }^{66}$. However, in recent years, two views have been presented of non-contentious cases; those of Professor Kimiduka and Professor Takahashi. Below, This article shall review those views, and then presents some questions.

\section{Current Theories of the Constitutional Status of Non-Contentious Cases}

In discussions over the limits of the jurisdiction of courts, so-called "objective litigation" has been the main issue. The non-contentious case was mostly concomitantly referred. However, in recent years, two theories have dealt directly with the relationship between non-contentious case and judicial power. Below, each view is discussed.

\section{(1) View of Professor Kimiduka ${ }^{67}$}

Professor Kimiduka's view tries to capture the non-contentious case in terms of its distance from the proper judicial power. He contends that the extrajudicial power which could be vested on the courts must involve a "dispute," and it must also involve "an appeal from one of the parties, the court, as a neutral department, takes part in the remedy, which comprises the realization of substantive legal rights with the function of declaration and maintenance of law, and which is suitable for processing by the courts ${ }^{68}$." Regarding the limits of authority that could be vested on the court, it is difficult to ease the requirement of the "concrete case," legal judgment, and finality in some sense 69 . Therefore, the line should be drawn where it can be achieved by relaxing the requirement of standing and the "interests of the complainants (uttae no rieki)."70 As seen above, his theory is based on the concept of "dispute resolution."

However, for non-contentious cases, he finds some sort of "dispute" there. There he contends that non-contentious case is a proceeding where the court, by an appeal of a party, applies the law, and confirm rights and duties with finality ${ }^{71}$. Then he refers to the views of Professor Kiyomiya and Professor Koji Sato, and points out the similarities between judicial power and the noncontentious case ${ }^{72}$.

In this way, Professor Kimiduka develops his theory based on the view that "dispute" remains the key concept. However, can the name change procedure mentioned earlier be included?

\footnotetext{
66 Nosaka, supra note 18 , at 47.

67 The contents of this section is re-construction of a part of my previous work. Non-Contentious Cases, supra note 4 , at 202-03.

68 Kimiduka Masaomi, Shihoken Teigi ni Tomonau Saibansho no Chukan Ryoiki- Kyakkansosho, Hishojiken Saiko 1 [Not in the Judicial Power' but in the Trials and Judgments of Courts I] Vol.22 No.3 Yokohama Hogaku 157 (2013).

69 Kimiduka Masaomi, Shihoken Teigi ni Tomonau Saibansho no Chukan Ryoiki- Kyakkansosho, Hishojiken Saiko 3[Not in the Judicial Power' but in the Trials and Judgments of CourtsIII] Vol.23 No.3Yokohama Hogaku 130 (2015).

70 Id.

${ }^{71}$ Kimiduka Masaomi, Shihoken Teigi ni Tomonau Saibansho no Chukan Ryoiki- Kyakkansosho, Hishojiken Saiko 2 [Not in the Judicial Power' but in the Trials and Judgments of Courts II] Vol.23 No.1 Yokohama Hogaku 15 (2014).

72 Id.
} 
Difficulties will arise by expanding the concept of "dispute" to include ex-parte proceedings, which do not have the characteristics of a "dispute."

\section{(2) View of Professor Takahashi ${ }^{73}$}

On the other hand, Professor Takahashi adopts a different approach. Professor Takahashi states that separation of powers is to be distributed by "legal nature" rather than "distribution of matter," 74 and conceived the authority of each division as legislative power as primitive law making, administrative power as law enforcement, and judicial power as the final ruling of the interpretation and application of the law ${ }^{75}$. In this way, the roles of each department are determined not by "matter" but by "legal nature," so flexibility is provided.

He has long defined judicial power as "the function, with legitimate appeal, under appropriate procedures, judge with finality on the controversy about interpretation and application of laws ${ }^{76}$." However, he said that it is difficult to imitate a "dispute" in name changing proceedings, which is an example of a non-contentious case ${ }^{77}$. Accordingly, "dispute" is removed from the definition of judicial power and it is corrected to the form "the function, with legitimate appeal, under appropriate procedures, confirm the interpretation and application of law with finality, and give effective remedy $78^{\prime \prime} 79$.

In the opinion of Professor Takahashi, where he points that in some areas it is difficult to find any "dispute" in non-contentious case proceedings, is also consistent with the stance of this article. It is noteworthy that he banished the concept of "dispute" from the definition of judicial power. Professor Kimiduka and the traditional view finds the concept of "dispute" a requisite element of authority, which can be vested in courts. Then they tried to include a "non-dispute" authority in that definition there. On the other hand, Professor Takahashi has tried to justify non-contentious cases by removing "dispute" from the definition of judicial power. It is an interesting approach and one way that remains open if a non-contentious case cannot be included in a "dispute."

\section{(3) Some Questions to Those Views ${ }^{80}$}

The views above present interesting perspectives from different individuals. First, Professor Kimiduka's view shares a basic proposition with the conventional view and is trying to grasp the authority given to the court based upon a "dispute." It is noteworthy that requirements of a "case" are stipulated although they are loosened. However, it is impossible to incorporate a "non-dispute"

\footnotetext{
73 The contents of this section is re-construction of a part of my previous work. Non-Contentious Cases, supra note 4 , at 207-08.

${ }^{74}$ Litigation, supra note 19 , at 46.

$75 \mathrm{Id}$.

76 Takahashi Kazuyuki, Shiho no Kannen [Concept of Judicial Power], in Koza Kenpogaku 6 Kenryoku no

Bunritsu 2, 23-24 (Higuchi Yoichi ed., Nihon Hyoronsha 1995).

77 Litigation, supra note 19 , at 49.

$78 \mathrm{Id}$.

79 Id., at 48-49.

80 The contents of this section is re-construction of a part of my previous work. Non-Contentious Cases, supra note 4 , at 207-08.
} 
into a "dispute" category ${ }^{81}$. If we include authorities such as name changing procedures in a "dispute," we must enlarge the concept. On the other hand, Professor Takahashi refuses to include "non-dispute" in "dispute." Therefore, he eliminates "dispute" from the definition of judicial power. However, then it is very hard to avoid the criticism that involves too much expansion of judicial power ${ }^{82}$.

As above, questions are presented to both approaches, the expansion of the concept of "dispute" and the expansion of "judicial power" itself. However, both of them; enlarge the meaning of dispute or the expansion of judicial power; have problems. At the same time, as evidenced by the fact that non-contentious cases were also seen under the Meiji Constitution, the court has historically been vested with a power not related to "dispute." The history seems to show that such an authority is suitable for courts. Unless judging non-contentious cases unconstitutional, we have to conceive those authorities as non-dispute, extrajudicial, and constitutional.

According to previous approaches, there were two methods for processing non-contentious cases: by imitating a dispute or expanding the remit of judicial power. However, there is another way; change the basis of justification according to the nature of the authorities ${ }^{83}$. Professor Kimiduka's approach was to vest to the court with the authority, which has the function of dispute resolution. Since "objective litigation" is a kind of litigation which has a certain degree of "dispute," the limit can be defined by referring to the distance from a "dispute." However, as non-contentious cases do not involve a dispute resolution process, there should be another measure. Rather than using a single criterion of "dispute", it may be necessary to separate criteria according to their functions ${ }^{84}$.

\section{Conclusion}

Unlike the United States, vesting extrajudicial authorities in the courts had been accepted without doubts in Japan. This is deeply rooted in constitutional history, although it has logical inconsistencies. Under the current Constitution, and not so far past, questions have arisen.

Academics developed theories and tried to answer the question by drawing a line in terms of the distance from the proper judicial power, or by eliminating the element of dispute from the definition of judicial power. However, both of them seem to go too far: too broad a definition of "dispute," or too large an expansion of "judicial power." Therefore, this article proposes another approach: rather than using a single criterion, separate criteria should be applied according to the functions provided. "Dispute" will work well with objective litigation because such a case has a dispute resolution function. However, it will not work well with non-contentious cases. If we do not want to expand the remit of judicial power, a suitable method for explaining and processing noncontentious cases must be identified.

To create separate criteria, a further investigation of the separation of powers is needed. In addition, the separation of powers will need to be investigated in functional way, which adheres to the traditional Japanese view of the separation of powers. However, a specific discussion goes beyond the scope of this article, but will be revisited in a future article.

\footnotetext{
81 Id., at 207.

82 Id., at 208.

83 Id., at 209.

84 See generally, Id.
} 